\title{
Comparison of ultrasound-guided supraclavicular block according to the various volumes of local anesthetic
}

\author{
Dae Geun Jeon, Seok Kon Kim, Bong Jin Kang, Min A Kwon, Jae Gyok Song, and Soo Mi Jeon \\ Department of Anesthesiology and Pain Medicine, College of Medicine, Dankook University, Cheonan, Korea
}

Background: The ultrasound guidance in regional nerve blocks has recently been introduced and gaining popularity. Ultrasound-guided supraclavicular block has many advantages including the higher success rate, faster onset time, and fewer complications. The aim of this study was to examine the clinical data according to the varied volume of local anesthetics in the ultrasound-guided supraclavicular block.

Methods: One hundred twenty patients were randomized into four groups, according to the local anesthetic volume used: Group $35(\mathrm{n}=30)$, Group $30(\mathrm{n}=30)$, Group $25(\mathrm{n}=30)$, and Group $20(\mathrm{n}=30)$. Supraclavicular blocks were performed with $1 \%$ mepivacaine $35 \mathrm{ml}, 30 \mathrm{ml}, 25 \mathrm{ml}$, and $20 \mathrm{ml}$, respectively. The success rate, onset time, and complications were checked and evaluated.

Results: The success rate (66.7\%) was lower in Group 20 than that of Group 35 (96.7\%) $(\mathrm{P}<0.05)$. The average onset times of Group 35, Group 30, Group 25, and Group 20 were $14.3 \pm 6.9 \mathrm{~min}, 13.6 \pm 4.5 \mathrm{~min}, 16.7 \pm 4.6 \mathrm{~min}$, and $16.5 \pm 3.7$ min, respectively. There were no significant differences. Horner's syndrome was higher in Group $35(\mathrm{P}<0.05)$.

Conclusions: In conclusion, we achieved $90 \%$ success rate with $30 \mathrm{ml}$ of $1 \%$ mepivacaine. Therefore, we suggest 30 $\mathrm{ml}$ of local anesthetic volume for ultrasound-guided supraclavicular block. (Korean J Anesthesiol 2013; 64: 494-499)

Key Words: Regional nerve blocks, Supraclavicular block, Ultrasound guidance.

\section{Introduction}

Supraclavicular block provides excellent anesthesia for upper limb surgery [1,2]. Moreover, ultrasound guidance in supraclavicular block has been introduced and gaining popularity [3]. Ultrasound-guided supraclavicular block has many advantages including the higher success rate, faster onset time, and fewer complications [4-6]. In the previous studies on the ultrasound- guided axillary blocks and interscalene blocks, the possibility of the reduced volume of local anesthetics was demonstrated [7-10]. However, there is some controversy in such reduced anesthetics volume in the ultrasound-guided supraclavicular block $[11,12]$.

In the previous studies on the minimum effective volume for the ultrasound-guided supraclavicular block, the Dixon and Massey up and down method (DUDM) and biased coin

Received: August 30, 2012. Revised: 1st, October 9, 2012; 2nd, October 25, 2012; 3rd, November 7, 2012. Accepted: November 11, 2012.

Corresponding author: Dae Geun Jeon, M.D., Department of Anesthesiology and Pain Medicine, College of Medicine, Dankook University, 16-6, Anseo-dong, Dongnam-gu, Cheonan 330-715, Korea. Tel: 82-41-550-6829, Fax: 82-41-550-6819, E-mail: timepain@hanmail.net

(c) This is an open-access article distributed under the terms of the Creative Commons Attribution Non-Commercial License (http:// creativecommons.org/licenses/by-nc/3.0/), which permits unrestricted non-commercial use, distribution, and reproduction in any medium, provided the original work is properly cited. 
design up and down method (BUDM) were used to calculate the minimum effective volume (MEV) 50, MEV90, and MEV95, respectively $[11,12]$. These effective volumes were speculated by statistical calculation. However, Orebaugh et al. [13] indicated that the results from the DUDM may be different from those of the clinical practice, and the comparison of the varied anesthetic volumes in the clinical practice has not been studied in the ultrasound-guided supraclavicular block.

The aim of this study was to examine the clinical data according to the varied volumes of local anesthetics in the ultrasound-guided supraclavicular block.

\section{Materials and Methods}

After the approval of Institutional Review Board and obtaining patients' written informed consent, one hundred twenty patients undergoing forearm and hand surgery were randomly assigned to one of four groups to receive ultrasoundguided supraclavicular block with $1 \%$ mepivacaine $35 \mathrm{ml}$ (Group 35), $30 \mathrm{ml}$ (Group 30), $25 \mathrm{ml}$ (Group 25), or $20 \mathrm{ml}$ (Group 20). Exclusion criteria included patients with diseases affecting sensory or motor functions of the upper extremity, pregnant patients, allergy to local anesthetics, and contraindication to regional anesthesia.

For ultrasound-guided supraclavicular block, an ultrasound machine (Vivid I ${ }^{\circledR}$, GE Yokogawa Medical Systems Ltd., Tokyo, Japan) and a $12 \mathrm{MHz}$ linear type probe were used. The supraclavicular fossa was scanned to locate the subclavian artery and brachial plexus cluster after skin preparation. After local infiltration of skin, a 22 gauge, $5 \mathrm{~cm}$, short beveled insulated needle (Stimuplex ${ }^{\circledR}$ A, B. Braun, Melsungen AG, Germany) was advanced from the lateral to medial in the long axis of the ultrasound beam. Once the needle tip was located around the

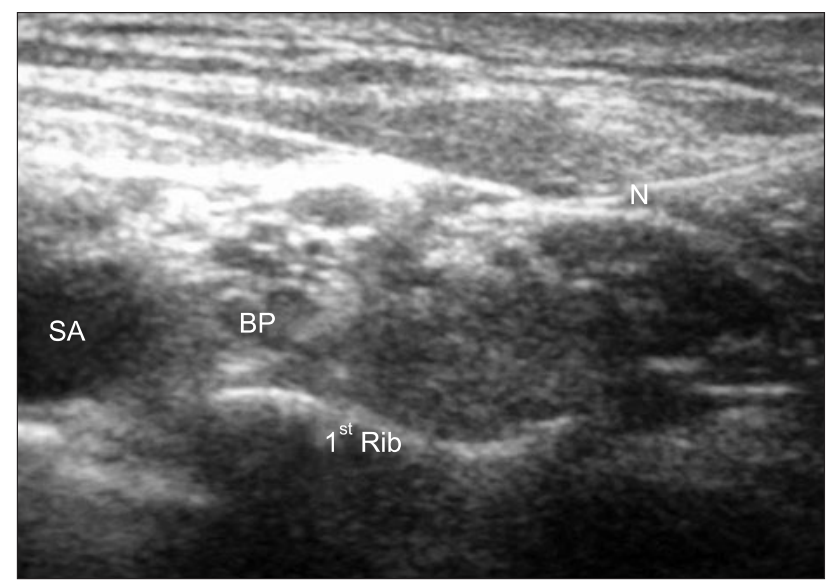

Fig. 1. Ultrasound image in the supraclavicular block. SA: subclavian artery, BP: brachial plexus, N: needle. brachial plexus cluster (Fig. 1), a nerve stimulator (Stimulpex ${ }^{\circledR}$, B. Braun, Melsungen AG, Germany) was turned on with 2 $\mathrm{Hz}$, starting from $1.0 \mathrm{~mA}$ down to $0.5 \mathrm{~mA}$. Local anesthetic was injected in real time with the presence of muscle twitch with the nerve stimulation. If no motor response was obtained, the injection was performed under ultrasound imaging alone without nerve stimulation. In order to avoid intraneural injection, we confirmed that the location of the needle tip was not in the nerves before each injection. However, the needle tip was not always visualized. Therefore, $0.5 \mathrm{ml}$ of $1.5 \%$ mepivacaine was injected as a test dose. If patients did not complain of paresthesia or pain, or the injection pressure was not high, the remaining dose of $1.5 \%$ mepivacaine was injected incrementally with withdrawing the needle. If local anesthetic did not reach some parts of the brachial plexus, the needle was repositioned until the appropriate image was obtained.

We checked the sensory anesthesia with 26 gauge needle every 5 minutes up to 30 minutes after injection of local anesthetic in all 5 cutaneous nerve distributions (musculocutaneous nerve: lateral side of the forearm, radial nerve: dorsum of the hand over the 2nd metacarpophalangeal joint, ulnar nerve: little finger, median nerve: medial thenar eminence, and medial cutaneous nerve: medial side of the forearm) by a research assistant who was blinded for over 30 minutes after the injection of local anesthetic. The onset of anesthesia was defined as a complete sensory anesthesia in each of the nerve distributions.

We analyzed the success rate in two aspects: the success rate of each nerve and all five nerves. The success rate of each nerve was named 'individual nerve's success rate', and the success rate of all five nerves was termed 'complete success rate.' The successful block of individual nerve was defined as the onset of sensory anesthesia in each nerve's distributions, and a complete successful block was defined as a complete sensory anesthesia in all 5 cutaneous nerve distributions of the forearm at 30 minutes after the local anesthetic injection and operability. Then, all patients were checked for complications such as Horner's syndrome, voice changes, and chest discomfort. The patients who had failed blockades had general anesthesia or sedation with midazolam and pethidine.

Statistical analysis was performed with SPSS version 12 . The sample size $(n=120)$ was determined based on the following criteria: a significance level of $5 \%$ and a power of $80 \%$ from the pilot study. The age, height, weight, and onset time of block were compared among the four groups by one-way analysis of variance (ANOVA) and Tukey post hoc tests. The age, height, weight, and body mass index were also compared between the successful and failed cases. For intergroup comparisons, the distribution of data was first evaluated for normality using the Shapiro-Wilk test. The normally distributed data and non- 
normally distributed data were compared using Student's and Mann-Whitney test, respectively. The sex, success rate, and the incidence of complications were compared using Chi-square test or Fisher's exact test. A P value $<0.05$ was considered significant.

\section{Results}

One hundred twenty patients were included in this study. There were no differences in the characteristics between the four groups (Table 1).

The complete success rates of Group 35, Group 30, Group 25 , and Group 20 were $96.7 \%, 90.0 \%, 80.0 \%$, and $66.7 \%$, respectively. The success rate of Group 20 was lower than that of Group 35 ( $\mathrm{P}<0.05)$ (Table 2). The individual success rate of the ulnar nerve and medial cutaneous nerve were lower than those of other nerves $(\mathrm{P}<0.05)$ (Table 2$)$.

The average height and weight in failed cases were larger than those in the successful cases $(\mathrm{P}<0.05)$ (Table 3). In Group 35 , one failure was operated under sedation only. In Group 30 , one failure was operated under sedation, and another two

Table 1. Demographic Data

\begin{tabular}{lcccc}
\hline & $\begin{array}{c}\text { Group 35 } \\
(\mathrm{n}=30)\end{array}$ & $\begin{array}{c}\text { Group 30 } \\
(\mathrm{n}=30)\end{array}$ & $\begin{array}{c}\text { Group 25 } \\
(\mathrm{n}=30)\end{array}$ & $\begin{array}{c}\text { Group 20 } \\
(\mathrm{n}=30)\end{array}$ \\
\hline Sex $(\mathrm{M} / \mathrm{F})$ & $19 / 11$ & $20 / 10$ & $18 / 12$ & $19 / 11$ \\
Age $(\mathrm{yr})$ & $43.3 \pm 18.8$ & $45.7 \pm 11.1$ & $40.0 \pm 16.2$ & $41.0 \pm 15.6$ \\
Height $(\mathrm{cm})$ & $166.0 \pm 9.7$ & $167.0 \pm 8.5$ & $168.0 \pm 9.0$ & $167.3 \pm 10.0$ \\
Weight $(\mathrm{kg})$ & $63.8 \pm 11.2$ & $65.6 \pm 11.7$ & $66.6 \pm 11.1$ & $64.6 \pm 11.2$
\end{tabular}

Data are mean \pm standard deviation. Group 35: supraclavicular block with $35 \mathrm{ml}$ of $1 \%$ mepivacaine, Group 30: supraclavicular block with $30 \mathrm{ml}$ of $1 \%$ mepivacaine, Group 25: supraclavicular block with $25 \mathrm{ml}$ of $1 \%$ mepivacaine, Group 20: supraclavicular block with $20 \mathrm{ml}$ of $1 \%$ mepivacaine. failures received general anesthesia. In Group 25, four failures were given sedation only, and 2 failures received general anesthesia. In Group 20, six failures were operated under sedation only, and four failures received general anesthesia (Table 4).

Table 3. Demographic Data of Successful Cases and Failed Cases

\begin{tabular}{|c|c|c|c|}
\hline & & Successful cases & Failed cases \\
\hline \multirow[t]{5}{*}{ Group 35} & $\operatorname{Sex}(M / F)$ & $18 / 11$ & $1 / 0$ \\
\hline & Age (yr) & $43.9 \pm 18.7$ & 23.0 \\
\hline & Height (cm) & $171(158-172)$ & 175.0 \\
\hline & Weight (kg) & $63.6 \pm 11.3$ & 72.0 \\
\hline & $\mathrm{BMI}\left(\mathrm{kg} \mathrm{m}^{-2}\right)$ & $23.0 \pm 2.9$ & 23.5 \\
\hline \multirow[t]{5}{*}{ Group 30} & $\operatorname{Sex}(M / F)$ & $18 / 9$ & $2 / 1$ \\
\hline & Age (yr) & $47.1 \pm 10.6$ & $32.2 \pm 3.8^{*}$ \\
\hline & Height (cm) & $166.3 \pm 8.0$ & $173.7 \pm 11.8$ \\
\hline & Weight (kg) & $61(56.5-74)$ & $72(65-76)$ \\
\hline & BMI $\left(\mathrm{kg} \mathrm{m}^{-2}\right)$ & $22.41(21.23-26)$ & $22.66(22.44-23.54)$ \\
\hline \multirow[t]{5}{*}{ Group 25} & $\operatorname{Sex}(M / F)$ & $12 / 12$ & $6 / 0$ \\
\hline & Age (yr) & $42.3 \pm 16.1$ & $31.0 \pm 14.6$ \\
\hline & Height (cm) & $166.1 \pm 8.9$ & $175.7 \pm 5.2^{*}$ \\
\hline & Weight (kg) & $64.2 \pm 10.3$ & $76.3 \pm 9.3^{*}$ \\
\hline & BMI $\left(\mathrm{kg} \mathrm{m}^{-2}\right)$ & $23.2 \pm 2.7$ & $24.7 \pm 1.9$ \\
\hline \multirow[t]{5}{*}{ Group 20} & $\operatorname{Sex}(M / F)$ & $12 / 8$ & $7 / 3$ \\
\hline & Age (yr) & $45.5 \pm 15.4$ & $32.2 \pm 12.6^{*}$ \\
\hline & Height (cm) & $164.8 \pm 8.9$ & $172.4 \pm 10.7^{*}$ \\
\hline & Weight (kg) & $61.9 \pm 10.6$ & $70.0 \pm 10.8$ \\
\hline & BMI $\left(\mathrm{kg} \mathrm{m}^{-2}\right)$ & $22.7 \pm 2.7$ & $23.5 \pm 2.1$ \\
\hline \multirow[t]{5}{*}{ Total } & $\operatorname{Sex}(M / F)$ & $62 / 38$ & $16 / 4$ \\
\hline & Age (yr) & $46(32.75-56.25)$ & $28.5(22.75-37.5)^{\dagger}$ \\
\hline & Height (cm) & $166(159-173)$ & $175.5(171-180)^{\dagger}$ \\
\hline & Weight (kg) & $63.8 \pm 10.1$ & $72.0 \pm 9.7^{*}$ \\
\hline & $\mathrm{BMI}\left(\mathrm{kg} \mathrm{m}^{-2}\right)$ & $23.1 \pm 2.9$ & $23.8 \pm 1.9$ \\
\hline
\end{tabular}

Data are mean \pm standard deviation and medians (interquartile range). Group 35: supraclavicular block with $35 \mathrm{ml}$ of $1 \%$ mepivacaine, Group 30: supraclavicular block with $30 \mathrm{ml}$ of $1 \%$ mepivacaine, Group 25: supraclavicular block with $25 \mathrm{ml}$ of $1 \%$ mepivacaine, Group 20: supraclavicular block with $20 \mathrm{ml}$ of $1 \%$ mepivacaine. $* \mathrm{P}<0.05$ compared with successful cases, using Student's t-test. ${ }^{\dagger} \mathrm{P}<0.05$ compared with successful cases, using Mann-Whitney test.

Table 2. The Success Rate of Individual Nerve and the Complete Success Rate of All Five Nerves

\begin{tabular}{|c|c|c|c|c|}
\hline & $\begin{array}{c}\text { Group } 35 \\
(\mathrm{n}=30)\end{array}$ & $\begin{array}{c}\text { Group } 30 \\
(\mathrm{n}=30)\end{array}$ & $\begin{array}{c}\text { Group } 25 \\
(\mathrm{n}=30)\end{array}$ & $\begin{array}{c}\text { Group } 20 \\
(\mathrm{n}=30)\end{array}$ \\
\hline \multirow[t]{2}{*}{ Median nerve } & 100 & 93.3 & 90.0 & $80.0 *$ \\
\hline & $(30 / 30)$ & $(28 / 30)$ & $(27 / 30)$ & $(24 / 30)$ \\
\hline \multirow[t]{2}{*}{ Radial nerve } & 100 & 100 & 93.3 & 93.3 \\
\hline & $(30 / 30)$ & $(30 / 30)$ & $(28 / 30)$ & $(28 / 30)$ \\
\hline \multirow[t]{2}{*}{ Musculocutaneous nerve } & 100 & 93.3 & 93.3 & 90.0 \\
\hline & $(30 / 30)$ & $(28 / 30)$ & $(28 / 30)$ & $(27 / 30)$ \\
\hline \multirow[t]{2}{*}{ Ulnar nerve } & 96.7 & 90.0 & 83.3 & $73.3^{*}$ \\
\hline & $(29 / 30)$ & $(27 / 30)$ & $(25 / 30)$ & $(22 / 30)$ \\
\hline \multirow[t]{2}{*}{ Medial cutaneous nerve } & 96.7 & 90.0 & 90.0 & $70.0 *$ \\
\hline & $(29 / 30)$ & $(27 / 30)$ & $(27 / 30)$ & $(21 / 30)$ \\
\hline All 5 nerves & 96.7 & 90.0 & 80.0 & $66.7 *$ \\
\hline (Complete successful block) & $(29 / 30)$ & $(27 / 30)$ & $(24 / 30)$ & $(20 / 30)$ \\
\hline
\end{tabular}

Data are expressed in percents. ( ) = the number of blocked patients/the number of total patients $(\mathrm{n}=30)$. Group 35: supraclavicular block with $35 \mathrm{ml}$ of $1 \%$ mepivacaine, Group 30: supraclavicular block with $30 \mathrm{ml}$ of $1 \%$ mepivacaine, Group 25: supraclavicular block with $25 \mathrm{ml}$ of $1 \%$ mepivacaine, Group 20: supraclavicular block with $20 \mathrm{ml}$ of $1 \%$ mepivacaine. ${ }^{*} \mathrm{P}<0.05$ compared with Group 35, using Fisher's exact test. 
Table 4. Demographic Characteristics of the Patients with an Unsuccessful Block

\begin{tabular}{|c|c|c|c|c|c|c|}
\hline $\begin{array}{l}\text { Patients with } \\
\text { failed block }\end{array}$ & Sex & $\begin{array}{l}\text { Age } \\
\text { (yr) }\end{array}$ & $\begin{array}{l}\text { Height } \\
(\mathrm{cm})\end{array}$ & $\begin{array}{l}\text { Weight } \\
\text { (kg) }\end{array}$ & Spared nerve & Supplementation \\
\hline G35-1 & M & 23 & 175 & 72 & Ulnar, Md.c & Sedation \\
\hline G30-1 & M & 35 & 181 & 80 & Ulnar, Md.c & Sedation \\
\hline G30-2 & M & 34 & 180 & 72 & Med, ulnar, Mc, Md.c & General anesthesia \\
\hline G30-3 & $\mathrm{F}$ & 28 & 160 & 58 & All five nerves & General anesthesia \\
\hline G25-1 & M & 18 & 168 & 64 & Ulnar & Sedation \\
\hline G25-2 & M & 22 & 178 & 80 & All five nerves & General anesthesia \\
\hline G25-3 & M & 32 & 172 & 65 & Ulnar, Md.C & Sedation \\
\hline G25-4 & M & 46 & 176 & 82 & Median, Md.c & Sedation \\
\hline G25-5 & M & 17 & 177 & 84 & Ulnar & Sedation \\
\hline G25-6 & M & 51 & 183 & 83 & Median, ulnar, radial, Mc & General anesthesia \\
\hline G20-1 & M & 18 & 180 & 70 & Median, ulnar, Md.c & Sedation \\
\hline G20-2 & M & 25 & 175 & 85 & Ulnar, Md.c & General anesthesia \\
\hline G20-3 & M & 45 & 183 & 82 & Median, ulnar, Md.c & Sedation \\
\hline G20-4 & M & 28 & 173 & 68 & All five nerves & General anesthesia \\
\hline G20-5 & M & 29 & 185 & 76 & Ulnar & Sedation \\
\hline G20-6 & $\mathrm{F}$ & 18 & 156 & 55 & Median, Md.c & Sedation \\
\hline G20-7 & $\mathrm{F}$ & 35 & 160 & 52 & Ulnar, Md.c & Sedation \\
\hline $\mathrm{G} 20-8$ & M & 23 & 174 & 75 & All five nerves & General anesthesia \\
\hline G20-9 & M & 47 & 180 & 74 & Ulnar, Md.c & General anesthesia \\
\hline G20-10 & $\mathrm{F}$ & 54 & 158 & 63 & Ulnar, Mc, Md.c & Sedation \\
\hline
\end{tabular}

G35: supraclavicular block with $35 \mathrm{ml}$ of $1 \%$ mepivacaine, G30: supraclavicular block with $30 \mathrm{ml}$ of $1 \%$ mepivacaine, G25: supraclavicular block with $25 \mathrm{ml}$ of $1 \%$ mepivacaine, G20: supraclavicular block with $20 \mathrm{ml}$ of $1 \%$ mepivacaine. M: male, F: female, Med: median nerve, Md.c: medial cutaneous nerve, Mc: musculocutaneous nerve.

Table 5. Onset Time of Each of the Five Terminal Nerves and All Five Nerves

\begin{tabular}{lcccc}
\hline & \multicolumn{3}{c}{ Time to onset (min) } \\
\cline { 2 - 5 } \multicolumn{1}{c}{ Sensory distribution } & $\begin{array}{c}\text { Group 35 } \\
\text { (n=30) }\end{array}$ & $\begin{array}{c}\text { Group 30 } \\
(\mathrm{n}=30)\end{array}$ & $\begin{array}{c}\text { Group 25 } \\
(\mathrm{n}=30)\end{array}$ & $\begin{array}{c}\text { Group 20 } \\
(\mathrm{n}=30)\end{array}$ \\
\hline Median nerve & $10.1 \pm 4.0$ & $10.6 \pm 4.7$ & $11.3 \pm 5.6$ & $12.0 \pm 4.4$ \\
Radial nerve & $9.1 \pm 4.7$ & $8.0 \pm 3.2$ & $9.2 \pm 6.0$ & $10.0 \pm 4.9$ \\
Musculocutaneous nerve & $9.8 \pm 4.7$ & $9.6 \pm 3.6$ & $10.8 \pm 5.0$ & $11.8 \pm 4.9$ \\
Ulnar nerve & $12.2 \pm 7.0$ & $12.4 \pm 5.3$ & $14.8 \pm 5.6$ & $13.3 \pm 4.4$ \\
Medial cutaneous nerve & $10.4 \pm 5.8$ & $12.0 \pm 5.2$ & $12.8 \pm 4.2$ & $12.3 \pm 4.1$ \\
All 5 nerves & $14.3 \pm 6.9$ & $13.6 \pm 4.5$ & $16.7 \pm 4.6$ & $16.5 \pm 3.7$ \\
\hline
\end{tabular}

Data are mean \pm standard deviation. Group 35: supraclavicular block with $35 \mathrm{ml}$ of $1 \%$ mepivacaine, Group 30 : supraclavicular block with $30 \mathrm{ml}$ of $1 \%$ mepivacaine, Group 25: supraclavicular block with $25 \mathrm{ml}$ of $1 \%$ mepivacaine, Group 20: supraclavicular block with $20 \mathrm{ml}$ of $1 \%$ mepivacaine.

The average onset times of the five nerves were $14.3 \pm 6.9$ $\min$ (Group 35), $13.6 \pm 4.5 \mathrm{~min}$ (Group 30), $16.7 \pm 4.6 \mathrm{~min}$ (Group 25), and $16.5 \pm 3.7 \mathrm{~min}$ (Group 20), respectively. There were no significant differences (Table 5).

Horner's syndrome in Group 35 was higher than other groups $(\mathrm{P}<0.05)$. There was no significant difference in the incidences of chest discomfort and voice change (Table 6).

\section{Discussion}

Systemic local anesthetic toxicity is still frequent and dose dependent. Therefore, reducing the dose of local anesthetic in regional anesthesia can contribute to the safety of regional anesthesia [1]. Some authors demonstrated the possibility
Table 6. Incidence of Side Effects in the Block

\begin{tabular}{lcccc}
\hline & $\begin{array}{c}\text { Group 35 } \\
(\mathrm{n}=30)\end{array}$ & $\begin{array}{c}\text { Group 30 } \\
(\mathrm{n}=30)\end{array}$ & $\begin{array}{c}\text { Group25 } \\
(\mathrm{n}=30)\end{array}$ & $\begin{array}{c}\text { Group 20 } \\
(\mathrm{n}=30)\end{array}$ \\
\hline Horner's syndrome & 76.7 & $43.3^{*}$ & $43.3^{*}$ & $46.7^{*}$ \\
& $(23 / 30)$ & $(13 / 30)$ & $(13 / 30)$ & $(14 / 30)$ \\
Chest discomfort & 13.3 & 16.7 & 16.7 & 6.7 \\
Voice change & $(4 / 30)$ & $(5 / 30)$ & $(5 / 30)$ & $(2 / 30)$ \\
& 3.3 & 3.3 & 0 & 3.3 \\
& $(1 / 30)$ & $(1 / 30)$ & $(0 / 30)$ & $(1 / 30)$ \\
\hline
\end{tabular}

Data are expressed in percents. ( ) = the number of symptomatic patients/the number of total patients $(\mathrm{n}=30)$.

Group 35: supraclavicular block with $35 \mathrm{ml}$ of $1 \%$ mepivacaine, Group 30: supraclavicular block with $30 \mathrm{ml}$ of $1 \%$ mepivacaine, Group 25: supraclavicular block with $25 \mathrm{ml}$ of $1 \%$ mepivacaine, Group 20: supraclavicular block with $20 \mathrm{ml}$ of $1 \%$ mepivacaine. $* \mathrm{P}<0.05$ compared with Group 35, using Chi-square test. 
of dose reduction in ultrasound-guided axillary blocks and interscalene blocks [7-10]. However, such possibility in ultrasound-guided supraclavicular block is controversial $[11,12]$.

Duggan et al. [11] estimated MEV95 and MEV50 to be $42 \mathrm{ml}$ and $23 \mathrm{ml}$, respectively, using DUDM. According to the study results, it was concluded that they could not reduce the volume of local anesthetic in ultrasound-guided supraclavicular block. Tran et al. [12] calculated MEV90 to be $32 \mathrm{ml}$, using BUDM for ultrasound-guided supraclavicular block in their study. This volume (32 ml) for $90 \%$ success rate was lower compared with the conventional technique using $40 \mathrm{ml}$ of local anesthetics. However their results were derived from the estimated values using BUDM. The limitations of Duggan et al.'s study were the wide confidence interval and no comparison with the conventional supraclavicular block [11]. The limitations of Tran et al. [11] were that the operators were trainees and 16-point scale including motor block was used for definition of successful block [12]. Therefore, we think that their estimated MEV90 (32 ml) may be larger than the local anesthetic volume for surgical anesthesia.

Orebaugh et al. [13] indicated that the results from DUDM do not seem to be easily translated to the clinical practice of peripheral nerve blockade. Therefore, we decided to perform a clinical comparison of the success rates with varied volumes of local anesthetics in ultrasound-guided supraclavicular block.

Before the commencement of the study, we planned the study with $40 \mathrm{ml}, 35 \mathrm{ml}, 30 \mathrm{ml}, 25 \mathrm{ml}$ and $20 \mathrm{ml}$ of local anesthetic based on the results (MEV $95=42 \mathrm{ml}$, MEV90 $=32 \mathrm{ml}$, and MEV $50=23$ $\mathrm{ml}$ ) from the previous studies $[11,12]$. However, the success rate of ultrasound-guided supraclavicular block with local anesthetic $35 \mathrm{ml}$ in the preliminary study was $94.7 \%$, which was similar to MEV95 in Duggan et al. [11]. For this reason, we excluded the 40 $\mathrm{ml}$ of local anesthetic volume in the study.

In general, the volume of local anesthetic for conventional supraclavicular block is known to be $40 \mathrm{ml}$ [14]. A 90.3\% success rate was achieved with the traditional technique using $40 \mathrm{ml}$ local anesthetics [15]. Ultrasound-guided techniques allowed for the reduction of the volume to $30 \mathrm{ml}$ of mepivacaine $1 \%$ with an equivalent success rate. Therefore, we could state that the volume of local anesthetics could be reduced. In addition, this volume was similar to MEV90 (32 ml) from Tran et al. [12]. However, this result was disappointing.

We expected to reduce the local anesthetic volume to be 20 $\mathrm{ml}$ in ultrasound-guided supraclavicular block before commencing the study, because the minimum effective volume could be reduced to $8-20 \mathrm{ml}$ in the ultrasound-guided axillary blocks $[7,8]$.

We suggest a possible explanation as to why we could not reduce the volume of local anesthetic to be $20 \mathrm{ml}$ as we expected in spite of using ultrasound. Cornish et al. $[16,17]$ injected contrast dye into the tunnel that surrounded brachial plexus and observed various patterns of flow within the tunnel. The dye did not spread homogeneously. With this observation, they asserted that the brachial plexus was surrounded within the rigid-walled tunnel as differently from the simple tubular structure, such as a sheath. In simple tubular structure, the local anesthetic injected at one point can spread throughout the tunnel. However, compartmentalization is present in the rigid tunnel, because the layers of connective tissue are not homogeneous. Therefore, the injection at one point in this rigid-walled tunnel may not spread to other nerves in the tunnel. With this theory, we presumed that the lower volume of local anesthetic was not able to spread to all nerves in this study.

At this point, we wondered why the reduction of local anesthetic in ultrasound-guided axillary block could be possible $[7,8]$. We assumed that four nerves (radial, median, ulnar, musculocutaneous nerve) could be distinguished by ultrasound, and injected 3-5 $\mathrm{ml}$ of local anesthetic to each nerve in the axillary region. However, in the supraclavicular region, each nerve could not be distinguished, it is located in the form of a cluster. Therefore, the local anesthetics should be filled in the tunnel, thus permitting no marked reduction in the volume from that used traditionally.

We also found that the height and weight were larger in the failed cases $(\mathrm{P}<0.05)$ (Table 3$)$. With this finding, we compared the differences under the condition with same local anesthetic volume (Group 35, Group 30, Group 25, and Group 20). As a result, the height and weight of failed cases were larger in Group 25 , and the height of failed cases was larger in Group 20. The age in Group 20, Group 30, and the total patients were lower in the failed cases $(\mathrm{P}<0.05)$. Therefore, the rigid-walled tunnels containing the brachial plexus in the supraclavicular region may be larger in the failed cases, but it is difficult to conclude such with the limited data of this study. Thus, we suggest that further studies should be performed to elucidate the factors influencing the success rate.

In our study, the success rates of ulnar and medial cutaneous nerve were lower than those of other nerves. This can be explained by the brachial plexus anatomy and the approach technique used in this study. The ulnar and medial cutaneous nerves are derived from the inferior trunk of brachial plexus. The approach to inferior trunk is difficult by lateral to medial approach in plane used in this study. As the needle advances through the brachial plexus bundle to reach the inferior trunk, there may be a nerve damage. We suggest that different approach techniques (e.g. multiple approach including the out of plane technique) should be applied to increase the success rate with the lower volume of local anesthetics.

There were some patients who complained of chest discomfort in this study. However, the chest X-ray was not taken since 
pneumothorax was not a concern, and no patients complained of chest discomfort after the surgery. We presume that transient hemi-diaphragmatic paresis may have occurred in some of the patients with the chest discomfort.

In conclusion, we achieved $90 \%$ success rate with $30 \mathrm{ml}$ of $1 \%$ mepivacaine. This result corresponds to MEV90 in the previous study using BUDM. Therefore, we suggest $30 \mathrm{ml}$ of local anesthetic volume for the ultrasound-guided supraclavicular block.

\section{References}

1. Wedel DJ, Horlokcer TT. Miller's Anesthesia. 7th ed. Philadelphia, Churchill Living Stone. 2010, p 1640.

2. Morgan GE, Mikhail MS, Murray MJ. Clinical Anesthesiology. 4th ed. New York, Lange Medical Books/McGraw-Hill Medical Publishing Division. 2006, p 332.

3. Stone MB, Wang R, Price DD. Ultrasound-guided supraclavicular brachial plexus nerve block vs procedural sedation for the treatment of upper extremity emergencies. Am J Emerg Med 2008; 26: 706-10.

4. Sites BD, Beach ML, Spence BC, Wiley CW, Shiffrin J, Hartman GS, et al. Ultrasound guidance improves the success rate of a perivascular axillary plexus block. Acta Anaesthesiol Scand 2006; 50 : 678-84.

5. Kapral S, Krafft P, Eibenberger K, Fitzgerald R, Gosch M, Weinstabl C. Ultrasound-guided supraclavicular approach for regional anesthesia of the brachial plexus. Anesth Analg 1994; 78: 507-13.

6. Perlas A, Lobo G, Lo N, Brull R, Chan VW, Karkhanis R. Ultrasoundguided supraclavicular block: outcome of 510 consecutive cases. Reg Anesth Pain Med 2009; 34: 171-6.

7. O'Donnell BD, Ryan H, O'Sullivan O, Iohom G. Ultrasound-guided axillary brachial plexus block with 20 milliliters local anesthetic mixture versus general anesthesia for upper limb trauma surgery: an observer-blinded, prospective, randomized, controlled trial. Anesth Analg 2009; 109: 279-83.

8. Harper GK, Stafford MA, Hill DA. Minimum volume of local anaesthetic required to surround each of the constituent nerves of the axillary brachial plexus, using ultrasound guidance: a pilot study. Br J Anaesth 2010; 104: 633-6.

9. McNaught A, Shastri U, Carmichael N, Awad IT, Columb M, Cheung $\mathrm{J}$, et al. Ultrasound reduces the minimum effective local anesthetic volume compared with peripheral nerve stimulation for interscalene block. Br J Anaesth 2011; 106: 124-30.

10. Kuruba SM, Singh SK. Ultrasound reduces the minimum effective local anaesthetic volume. Br J Anaesth 2011; 106: 600-1.

11. Duggan E, Beheiry HE, Perlas A, Lupu M, Nuica A, Chan VW, et al. Minimum effective volume of local anesthetic for ultrasoundguided supraclvicular brachial plexus block. Reg Anesth Pain Med 2009; 34: 215-8.

12. Tran de QH, Dugani S, Correa JA, Dyachenko A, Alsenosy N, Finlayson RJ. Minimum effective volume of lidocaine for ultrasoundguided supraclavicular block. Reg Anesth Pain Med 2011; 36: 466-9.

13. Orebaugh SL, Williams BA, Bigeleisen PE. The up-down methodology and practical peripheral nerve blockade. Reg Anesth Pain Med 2010; 35: 480-1.

14. Jankovic D, Wells C. Regional Nerve Blocks. 2th ed. Vienna, Blackwell Science. 2001, pp 67-70.

15. Jeon DG, Kim WI. Comparison of a supraclavicular block showing upper arm twitching response with a supraclavicular block showing wrist or finger twitching response. Korean J Anesthesiol 2010; 58: 464-7.

16. Cornish PB, Leaper CJ, Hahn JL. The "axillary tunnel": an anatomic reappraisal of the limits and dynamics of spread during brachial plexus blockade. Anesth Analg 2007; 104: 1288-91.

17. Cornish PB, Leaper C. The sheath of the brachial plexus: fact or fiction? Anesthesiology 2006; 105: 563-5. 